SŁAWOMIR KŁOSOWSKI

\title{
The application \\ of organizational \\ restructuring \\ in enterprise strategic \\ management process
}

\section{Introduction}

The aim of the paper is to present the concept of enterprise organizational restructuring process, its application in strategic management process. The article consists of three main chapters. The first one demonstrates the reasons for choosing the set of problems concerning organizational restructuring, its application dilemmas in enterprise strategic management process. The second chapter describes enterprise restructuring, its typology, areas of application in organizations. The third one concentrates on one of the model of enterprise restructuring, that is organizational restructuring, its process with key areas of essential analysis. The concept of enterprise organizational restructuring process with the assessment model of organizational restructuring efficiency is being presented.

\section{Reasons for choosing a topic}

Ph.D. Sławomir Kłosowski University of Zielona Góra
Increasing dynamics of change surrounding enterprises, high turbulence and instability of functioning conditions, enforce them to undertake permanent adaptive activities. 
In order to conduct adaptive activities effectively, organizations indentify and analyse exogenous and endogenous factors affecting its functioning. Although exogenous factors are mostly independent from company, their identification and anticipation constitute first essential feature, to achieve a company's success. The second essential feature is identification and analysis of endogenous factors, on which, opposite to exogenous factors, the company has an influence. The lack of permanent adaptive activities can lead a company to inevitable implementation of essential, fundamental changes in organisational structure and organisational processes. In that case there is a need for preparation and implementation of enterprise restructuring programme.

\section{Enterprise restructuring}

The essence of restructuring is change. Permanently changing environment and changing organization itself may lead to the crisis situation and the need of implementation of restructuring. The term of enterprise restructuring is being defined and understood differently by many authors. That's why in order to understand the essence of restructuring, different definitions of enterprise restructuring and its typology have been presented:

1. "Corporate restructuring has been defined as a major change in a firm's asset portfolio accompanied by a change in strategy" (Hoskisson and Turk 1990, p. 459).

2. According to Bicksler and Chen "Corporate restructuring has been defined as a strategy to enhance the firm's value" (Hurry, 1993, p. 70).

3. "Restructuring can encompass a broad range of transactions, including selling lines of business or making significant acquisitions, changing capital structure through infusion of high levels of debt, going private, and even changing the internal organization of the firm" (Singh 1993, p. 148).

Cited definitions show the relationship between changes caused by corporate restructuring and changes in corporate strategy. This is a very important aspect of research of corporate restructuring. Furthermore there are many other authors, which are being engaged in restructuring research (Myers, 1977, Heugens and Schenk 2004, Liao 2005, Weston et al 1998, Schüsselbauer 1999, Barkema and Schijven 2008), showing the importance of this area of knowledge.

Enterprise restructuring action occurs in three types (Bowman and Singh 1993, p. 6, Gibbs 1993, p. 51):

- business portfolio restructuring,

- financial restructuring, 
- organizational (operational) restructuring.

In literature many researchers describe solely one type of restructuring, but often, in practice there are at least two types of restructuring, which are being implemented simultaneously by an organisation. Restructuring can be either a company's response to a crisis situation or can be used as a tool contributing to company's development.

\section{Organizational restructuring process}

Restructuring type which is being often taken under consideration by many researcher is organisational restructuring. The term of enterprise organizational restructuring is also being defined and understood differently by many authors. Here there are some of the definitions of the notion found in literature:

1. "Organizational restructuring is intended to increase the efficiency and effectiveness of management teams through significant changes in organizational structure, often accompanied by downsizing" (Bowman, Singh 1993, p. 6).

2. W. McKinley and A.G. Scherer (2000, p. 736) define organizational restructuring "as any major reconfiguration of internal administrative structure that is associated with an intentional management change program".

3. "Organizational restructuring ... implies the recombination of existing subunits, leaving the scope of the firm." (Barkema, Schijven 2008, p. 706).

There are many other authors, which are being engaged in research of organizational restructuring (Balogun, Johnson 2004, Farjoun 2001, Jones 2002, Lee, Teo 2005, Rondeau, Wagar 2003). With this term is directly connected an organizational process as well as organizational structure. In other words organizational restructuring is defined as an essential, having strategic character, change of organizational structure and organizational processes, in order to augment a company functioning's efficiency. Organizational processes, organizational structure and its changes are key elements of the definition and the background for the concept of enterprise organizational restructuring and its determinants.

\section{Concept of enterprise organizational restructuring}

The concept of enterprise organisational restructuring consists of 6 main steps. Those are: identification of need of organizational restructuring, enterprise strategic diagnosis, analysis of external and internal determinants, preparation 
of organizational restructuring programme, implementation of organizational restructuring programme and control of organizational restructuring programme.

The first step is to identify the need of organizational restructuring implementation. Proper identification, at the early stage, may generate less radical organizational restructuring programme. The next step is to perform the enterprise strategic diagnosis, with the use of strategic controlling methods such as SWOT (TOWS) analysis, BCG matrix, ADL matrix, VIRO framework, Five Forces Analysis, Value Chain Analysis, Balanced Scorecard, than analysis of organizational structure, its dimensions: configuration, centralization, specialization, standardization and formalization (Pugh at all 1968), analysis of organizational processes and financial situation of a company (economic analysis). During the diagnostic process the following external and internal determinants analysis should be taken under consideration.

External determinants analysis:

- economic determinants,

- political and legal determinants,

- social and cultural determinants,

- technological determinants.

Internal determinants analysis:

- corporate strategy,

- management style,

- manager's skills,

- management methods,

- other employee's skills,

- size of organization,

- life cycle of organization,

- organizational culture,

- technology.

The last three steps of the concept consist of preparation of organizational restructuring programme, which can be done by managers or externals experts; implementation of organizational restructuring programme, one of the most difficult point of the organizational restructuring process and finally, control of organizational restructuring programme, with the use of controlling methods. Figure 1 shows the concept of the enterprise organizational restructuring process. 


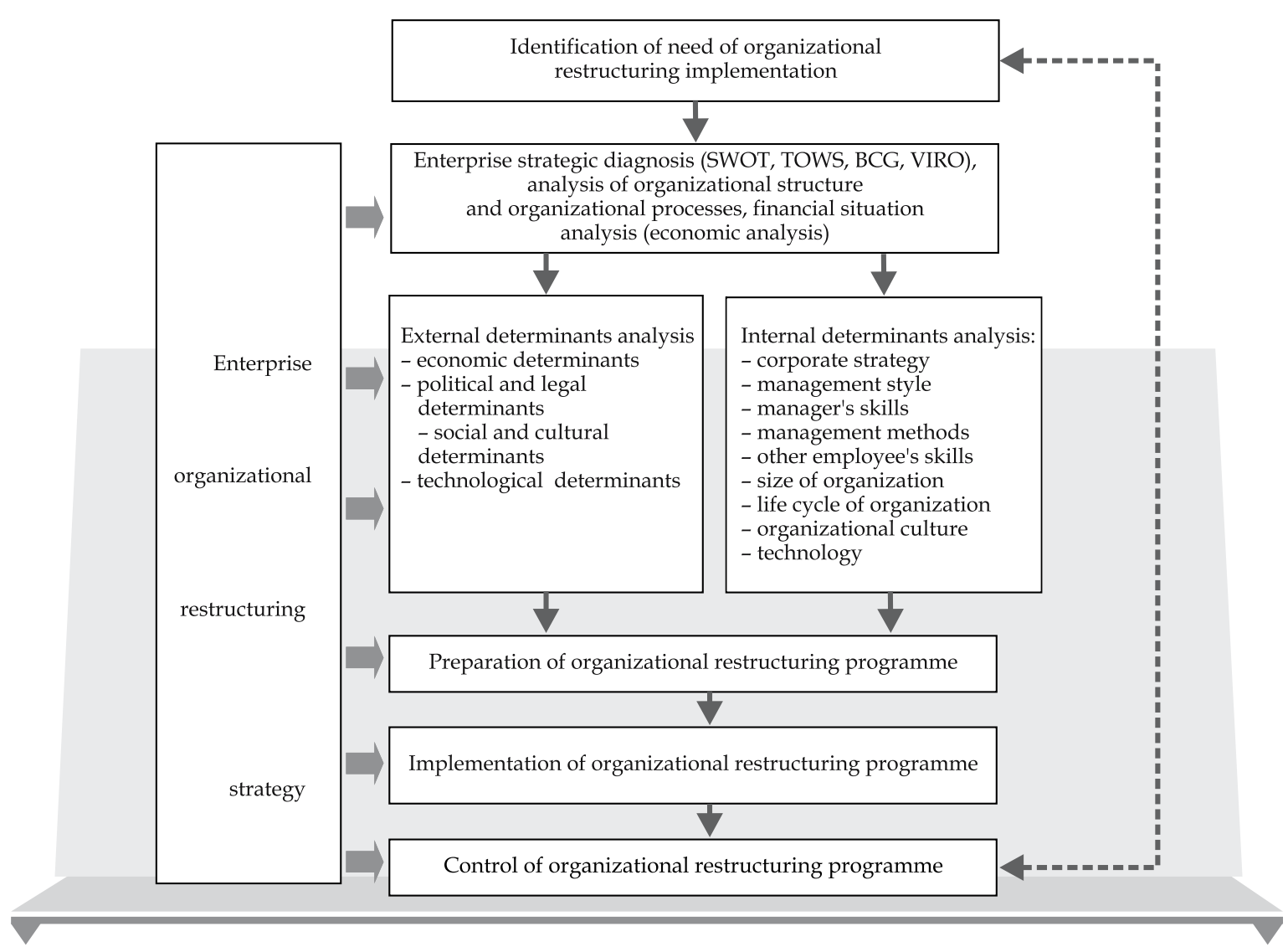

Fig. 1. Concept of enterprises organizational restructuring process

Source: own study

The main idea of the concept is to identify, analyse and take under consideration during enterprise organisational restructuring process its external and internal determinants. In author's opinion, companies not following the concept of organisational restructuring may not achieve their goals and will need to carry out the process again. In order to control the results of the organizational restructuring, it has been chosen a model focusing on three main measurements, that is quality of services or products (qualitative factor), level of costs (quantitative factor) and level of intellectual capital understood as human capital, organizational capital and client capital (qualitative and quantitative factor). Each company should strive to increase the quality of its services (products) and a level of intellectual capital and decrease a level of costs during and as a result of organizational restructuring process. Not identifying and 
taking determinants under consideration may lead to opposite results. Figure 2 presents the assessment model of organizational restructuring process.

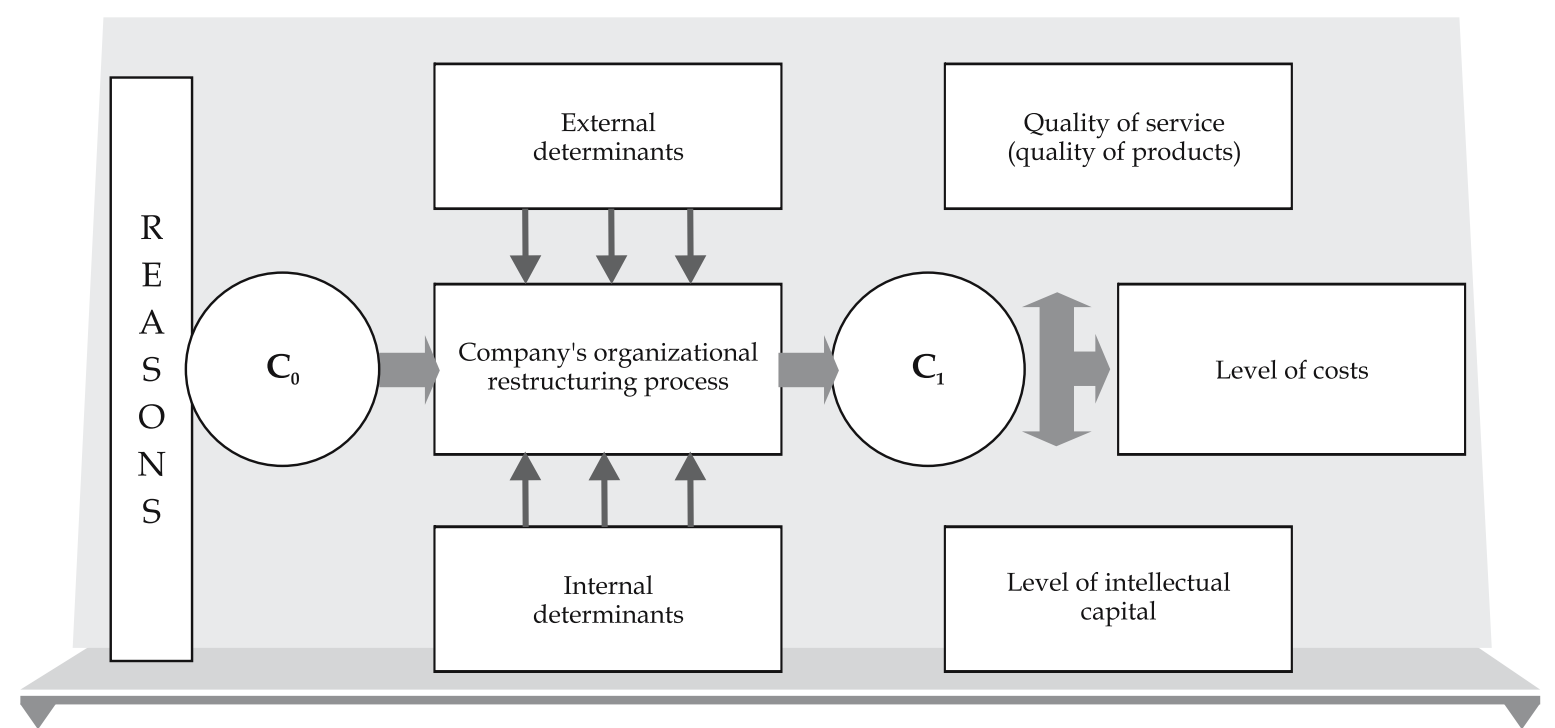

Fig. 2. Assessment model of organizational restructuring efficiency

Source: own study

The difficult point is not to determine the beginning of organizational restructuring process but to define its end. It is essential to perform properly the measurements, before the process $-C_{0}$ and after it $-C_{1}$. Quality of services may be measured with the use of survey (before and after), the level of costs may be measured with the use of controlling methods, in this point of the process, the operational controlling methods. The level of intellectual capital should be measured with appropriately selected tools, respectively to human capital, organizational capital and client capital.

\section{Conclusions}

Changing environment, its instability, companies' internal development enforce them to prepare and implement organizational restructuring as a response to external or internal crisis situation. Organizational restructuring involves changes in organizational structure and organizational processes, that is why its successful implementation is a sine qua non condition to achieve company's "efficiency and effectiveness". That is a reason for further detailed 
study and research of organizational restructuring, its external and internal determinants and its interdependence.

\section{Summary}

The application of organizational restructuring in enterprise strategic management process

The aim of the paper was to present the concept of enterprise organizational restructuring process, its application in strategic management process. There was presented enterprise restructuring, its typology, areas of application in organizations with concentration on organizational restructuring process. The concept of enterprise organizational restructuring process consists of 6 main steps. Those are: identification of need of organizational restructuring, enterprise strategic diagnosis, analysis of external and internal determinants, preparation of organizational restructuring programme, implementation of organizational restructuring programme and control of organizational restructuring programme. The assessment model of organizational restructuring efficiency focuses on three main measurements, that is quality of services or products (qualitative factor), level of costs (quantitative factor) and level of intellectual capital, that is human capital, organisational capital and client capital (qualitative and qualitative factor). Changing environment, its instability, the need of continuous companies' internal development is a reason for further, more detailed study and research of organizational restructuring, which may be always used as a appropriate response to external or internal crisis situation.

Keywords: organizational restructuring, organizational structure, restructuring programme

\section{Streszczenie}

\section{Zastosowanie restrukturyzacji organizacyjnej $w$ procesie zarządzania strategicznego przedsiębiorstwa}

Celem artykułu było przedstawienie koncepcji restrukturyzacji organizacyjnej przedsiębiorstwa, jej zastosowania w procesie zarządzania strategicznego. Przedstawiona została restrukturyzacja przedsiębiorstwa, jej typologia, obszary 
Stowa

zastosowań w organizacjach, ze szczególnym uwzględnieniem restrukturyzacji organizacyjnej. Koncepcja restrukturyzacji organizacyjnej składa się $\mathrm{z}$ sześciu głównych etapów. Jest to identyfikacja potrzeby wprowadzenia restrukturyzacji organizacyjnej, diagnoza strategiczna przedsiębiorstwa, analiza zewnętrznych i wewnętrznych determinant, przygotowanie programu restrukturyzacji organizacyjnej, wdrożenie programu restrukturyzacjiorganizacyjnejikontrolaprogramurestrukturyzacji organizacyjnej. Model oceny sprawności restrukturyzacji organizacyjnej koncentruje się na trzech głównych miarach, które dotycząjakości usług lub produktów (miernikjakościowy), poziomu kosztów (miernik ilościowy) i poziomu kapitału intelektualnego przedsiębiorstwa, rozumianego jako kapitału ludzkiego, kapitału organizacyjnego i kapitału klienta (miernik jakościowo-ilościowy). Zmiany otoczenia, jego niestabilność, potrzeba ciągłego rozwoju przedsiębiorstwa jest powodem konieczności przeprowadzenia dalszych, bardziej szczegółowych badań w zakresierestrukturyzacji organizacyjnej, ponieważ może być ona zawsze używana jako skuteczna odpowiedź na zewnętrzną lub wewnętrzną sytuację kryzysową.

kluczowe: restrukturyzacja organizacyjna, struktura organizacyjna, program restrukturyzacji

\section{References}

1. Balogun J., Johnson G. (2004), Organizational Restructuring and Middle Managers Sensemaking, Academy of Management Journal, volume 47, no 4.

2. Barkema H. G., Schijven M. (2008), Toward unlocking the full potential of Acquisitions: the role of Organizational restructuring, Academy of Management Journal, , volume 51, no. 4.

3. Bowman E.H., Singh H. (1993), Corporate restructuring: reconfiguring the firm, Strategic Management Journal, volume 14.

4. Farjoun M. (2001), Organizational restructuring: Perpetuating and Constraining Effects, Academy of Management Review, volume26, no 3.

5. Gibbs P.A. (1993), Determinants of corporate restructuring: the relative importance of corporate governance, takeover threat and free cash flow, Strategic Management Journal, Vol. 14, Special Issue.

6. Heugens P.P.M.A.R., Schenk H. (2004), Rethinking corporate restructuring, Journal of Public Affairs, volume 4, no 1. 
7. Hoskisson R.E., Turk T.A. (1990), Corporate restructuring: Governance and control limit of the internal capital market, Academy of Management Review, volume 15 , no 3.

8. Hurry D. (1993), Restructuring in the global economy: the consequences of strategic linkages between Japanese and U.S. firms, Strategic Management Journal, volume 14.

9. Jones M.T. (2002) Globalization and Organizational Restructuring: A Strategic Perspective, Thunderbird International Business Review, volume 44, nr 3.

10. Lee G., Teo A. (2005), Organizational Restructuring: Impact on Trust and Work Satisfaction, Asia Pacific Journal of Management, nr 22.

11. Liao J. (2005), Corporate restructuring, performance and competitiveness: an empirical examination, Competitiveness Review, volume 15, no 1.

12. McKinley W., Scherer A.G. (2000), Some unanticipated consequences of organizational restructuring, Academy of Management Review, volume 25, no 4.

13. Myers S. C., Determinants of corporate borrowing, Journal of Financial Economics, zeszyt 5, nr 2, 1977.

14. Pugh D.S, Hickson D.J., Hinings C.R., Tuner C. (1968), Dimensions of Organization Structure, Administrative Science Quarterly, volume 13, no 1.

15. Rondeau K.V., Wagar T.H., Downsizing and Organizational Restructuring: What is the Impact on Hospital Performance?, International Journal of Public Administration, zeszyt 26, nr 14, 2003.

16. Singh H. (1993), Challenges in researching corporate restructuring, Journal of Management Studies, volume 30, January.

17. Schüsselbauer, G. (1999), Privatisation and Restructuring in Economies in Transition: Theory and Evidence Revisited, Europe-Asia Studies, volume 51 no. 1.

18. Weston J.F., Jawien P.S., Levitas E.J. (1998), Restructuring and its implications for business economies, Business Economies, volume 33. 